Research, part of a Special Feature on Ecological Restoration in Northern Regions

\title{
A Social-Ecological System Approach to Analyze Stakeholders' Interactions within a Large-Scale Rangeland Restoration Program
}

\author{
$\underline{\text { Thorunn Petursdottir }}^{1}$, Olafur Arnalds $^{2}, \underline{\text { Susan Baker }}^{3}, \underline{\text { Luca Montanarella }}^{1}$ and $\underline{\text { Ás L L. Aradóttir }}^{2}$
}

\begin{abstract}
Large-scale restoration projects are normally part of a complex social-ecological system where restoration goals are shaped by governmental policies, managed by the surrounding governance system, and implemented by the related actors. The process of efficiently restoring degraded ecosystems is, therefore, not only based on restoring ecological structure and functions but also relies on the functionality of the related policies, the relevant stakeholder groups, and the surrounding socioeconomic and political settings. In this research, we investigated the SES of rangeland restoration in Iceland to estimate whether social factors, such as stakeholders' attitudes and behavior, can be used to evaluate the effectiveness of agrienvironmental policies on rangeland restoration and improved land management. We used qualitative approaches, interviewing 15 stakeholders. Our results indicate that social factors such as attitude toward restoration and land management practices can be used as indicators to evaluate the effectiveness of restoration policies. They also strongly indicate that lack of functionality in the governance system of social-ecological systems can reduce the desired progress of policies related to large-scale natural resource management projects, such as rangeland restoration, and possibly halt the necessary paradigm shift among stakeholders regarding improved rangeland management.
\end{abstract}

Key Words: agri-environmental policies; ecological restoration; evaluation; natural resource management; social-ecological systems

\section{INTRODUCTION}

Ecological restoration is the process of assisting the recovery of an ecosystem that has been degraded, damaged or destroyed. - Society for Ecological Restoration Science and Policy Working Group (SER) (2004).

The desired outcome of restoration is a resilient and selfsustaining ecosystem with respect to structure, species composition, and function. The restored system should also be integrated into the larger landscape and support the sustainable livelihood of societies that rely on using land resources (SER and IUCN 2004). Such coupled human natural systems are defined as social-ecological systems (SESs), encompassing distinct but interacting subsystems and internal variables (Anderies et al. 2004). An SES defines the intricate links between an ecological and a social system and how they affect and shape each other (Ostrom 2009). Its sustainability relies on well-structured policies, as well as efficient institutional governance and cooperative resource users, all aiming to sustain and strengthen the functional capacity of the SES (Holling 2001).

An SES of ecological restoration builds on interventions aiming at repairing degraded ecosystems and seeks to support the related interactions between humans and nature (Bradshaw and Bekoff 2001, Hobbs et al. 2011). Even though the restoration of ecosystem structure and functions are given as the main objectives for restoration (SER 2004), the process of sustaining or restoring ecosystems is also highly related to the motivation of related stakeholder groups and the effectiveness of the correspondent socioeconomic and political settings (Ostrom 2009, Hobbs et al. 2011). These multiple approaches are emphasized in the design of restoration programs and, in recent years, they are also stretching into the evaluation of restoration outcomes (Clewell and Aronson 2006, Aronson et al. 2010).

The methods of economics are increasingly used to evaluate the achievements of ecological restoration, in addition to the standard measurements of ecological parameters such as soil and vegetation components (e.g., Herling et al. 2008, Weber and Stewart 2008). Economic approaches can capture some of the market value of restoration derived from the actual use of a restored ecosystem good or service but are vaguer concerning the nonmarket values that are not expressed in prices (Daly and Farley 2004). The most effective leverage points for successful restoration and improved land management practices may not even lie within the economic system, but instead in social factors like rules, information transfers, and paradigms constructed around the related SESs (Meadows 2008). Stakeholders' attitudes and/or behavior and the level of consistency within the governance system may, therefore, facilitate restoration activities and progress, or cause dysfunction within the SESs that can lead to reversal or even elimination of the desired ecological progress (Berkes and

\footnotetext{
${ }^{1}$ Institute for Environment and Sustainability (IES), European Commission, Joint Research Centre (JRC), ${ }^{2}$ Faculty of Environmental Sciences, Agricultural University of Iceland, ${ }^{3}$ Cardiff School of Social Sciences
} 
Folke 2000, Hobbs 2007, Hobbs et al. 2011). Achieving successful restoration outcomes requires the design of new approaches that can measure and link both ecological functions and human well-being (O'Farrell et al. 2011).

To investigate the possible effects of social factors on restoration outcomes we explored the SESs of large-scale rangeland restoration in Iceland, focusing on the system's main stakeholder groups and their interrelationships. We used Iceland as a case study because the country's government has supported and financed restoration of degraded rangeland and improved land management for over a century. The long-term effectiveness of restoration and sustainable land management policies have, however, never been evaluated. For this study, we interviewed selected stakeholders about their attitudes toward rangeland restoration and land management practices. We also asked about their views on related policies and the governance system to assess whether social factors, such as stakeholders' attitudes and behavior, could be used as indicators for evaluating restoration impacts and more generally in relation to sustainable land management practices.

\section{METHODS}

\section{Background}

\section{Sheep farming, rangeland management, and restoration}

Livestock farming has been practiced in Iceland ever since the country was settled in the late 9th century. From the 13th century, sheep farming has been one of the most important sources of subsistence in Iceland (Ingimundarson 2010), and since early 20th century, this farming has been mainly geared toward the meat production market. According to the Icelandic Agricultural Statistic (IAS) (2010), there were 1318 sheep farms and 138 mixed sheep/dairy farms operating in 2008, compared with 581 dairy farms. The average farm holds around 300 adult sheep, and the average farmer is 54 years old (IAS 2010). The majority of the farmsteads are located in lowland areas, with the lowest density near urban areas (Jóhannesson 2010).

Because of Iceland's northerly location and erodible volcanic soils, its pristine ecosystems were highly vulnerable to grazing and the wood harvesting practiced by the settlers. Frequent volcanic eruptions and a harsh climate made the ecosystems even more fragile and less resilient in the face of human intervention (McGovern et al. 2008). Severe loss of fertile soil and vegetation throughout the centuries created vast areas of degraded ecosystems that are, to this day, still dysfunctional to some extent (Arnalds and Barkarson 2003). Their natural succession is often hindered by instability of the soil surface, arising from factors like erosion, cryoturbation, lack of nutrients in the topsoil layer, and ongoing unsustainable land use (Arnalds 2008).
Icelandic sheep farming practices have changed over the past 50 years, even though a significant proportion of the country is still used as rangeland. Earlier, the sheep were commonly grazed all year round, but a strong focus on breeding and improved winter fodder has led to shorter grazing periods, down to approximately 6 months on average (JuneNovember). Early spring and late autumn, the flocks are commonly grazed in fenced pastures next to the farm. However, rangeland management in the summer is generally still based on old traditions, rooted in centuries-old legislation that allows for communal grazing areas, or commons, provided by local communities for grazing animals (Barkarson and Johannesson 2009). In late June, the farmers release their sheep into summer rangelands in the lowlands (commonly held in private ownership but seldom entirely fenced off from the neighboring estates) or highland commons, where the sheep roam free until they are rounded up in September and brought back home again (Arnalds and Barkarson 2003). Sheep farmers still have very strong legal rights regarding land use and access to unenclosed land, which has caused conflicts in some regions over the changing land-use system resulting from changes in ownership of farmsteads, with a growing number of landowners who are not engaged in farming (Arnalds 2005).

In recent decades, many farmers have practiced restoration of natural or near-natural systems on their private lands, both on their own and in collaboration with the governments through public projects. In some regions of the country, farmers have also created local restoration nongovernmental organizations (NGOs) targeting collaborative restoration work in the commons (Crofts 2011). The most common restoration methods are spreading organic residue (e.g., manure or old hay) and/or spreading inorganic fertilizer, combined with restricted grazing while the area is undergoing a restoration process (Pétursdóttir 2011).

\section{The governance system for sheep farming, rangeland management, and restoration}

The Icelandic government approved the first environmental Act on soil conservation and afforestation at the beginning of the 20th century (Runólfsson and Agústsdóttir 2011). It was followed by the establishment of an environmental agency (known today as the Soil Conservation Service (SCSI)), under the auspices of the Ministry of Agriculture and the Agricultural Society (AS) (Crofts 2011). In the mid-20th century, the agency achieved self-autonomy, but links to the AS existed formally until 1996 (Alpingi 1996). A further division between the agricultural and environmental agencies took place in 2008, when the SCSI was transferred from the Ministry of Agriculture to the Ministry of Environment.

Agricultural policies in the 20th century focused primarily on marketing and pricing of agricultural produce (Stefánsson 
1998). The period between 1960 and 1980 was largely driven by production policies and a subsidy system that encouraged sheep farmers to increase production, regardless of domestic market needs. The excess meat production was exported to external markets and, in the late 1970s, the Icelandic market consumed only around 9800 tons of the 15,400 tons produced annually (Stefánsson 1998). Meat exportation was unprofitable, and in the early 1980s, the government finally removed the export subsidies and make drastic changes to subsidize the system through the use of quotas (Arnalds and Barkarson 2003). The importance of sustainable land use and environmental protection in sheep farming was stated for the first time in the Agricultural Act of 1993.

Another significant strategic change took place after 2000, when a new sheep farming subsidy system was approved by the government. As before, all farmers that had production quotas were entitled to get subsidies, but under the new agreement, a part of the total payment was directly linked to a quality management program. The agricultural Act of 1993 and the subsidy agreement in 2000 reshaped policies on rangeland restoration and sustainable land use and provided the first signs of an integrated agri-environmental policy on sheep farming and sustainable land management (Arnalds and Barkarson 2003).

The period between 1960 and 1980 was also, however, driven by conservation policies (Aradóttir and Petursdottir 2011). In 1971, one of the government's policy targets was the creation of a national strategy on restoration and sustainable use of resources (Croft 2011). In 1974, the Icelandic parliament followed this up by approving the establishment of a statefunded 5-year program to support restoration, afforestation, and improvement in land management (Arnalds 2005).

Throughout the 20th century, the AS provided consultation to sheep farmers, with a strong focus on breeding and improved winter fodder, but a limited number of advisors served the whole country (Jónsson 1985). In the early 1990s, the newly established Farmers Association (FA) started to develop regional advisory centers to provide more robust agricultural consultation (Bjarnason 1992). During the same period, the SCSI established district offices, parallel to the agricultural advisory centers, and strengthened its work in the field of agrienvironmental research, which had previously mostly been served by an agricultural research institute (Crofts 2011). In 1990, the SCSI also established a cost-share restoration project, "Farmers Heal the Land" (FHL), which is based on collaboration between farmers and the SCSI but without direct participation of the FA (Arnalds 2005). The main reason behind its establishment was to use direct and indirect incentives to trigger rangeland restoration and improved land management; however, it also aimed to find new ways to build collaboration and mutual trust between farmers and the SCSI (Arnalds 2005).The FHL project and the following
Fig. 1. General overview of soil erosion in Iceland and the geographical location of Skaftarhreppur and Skutustadahreppur. (The map is based on results from a national survey on soil erosion, published in 1997 (Arnalds et al. 2001)).

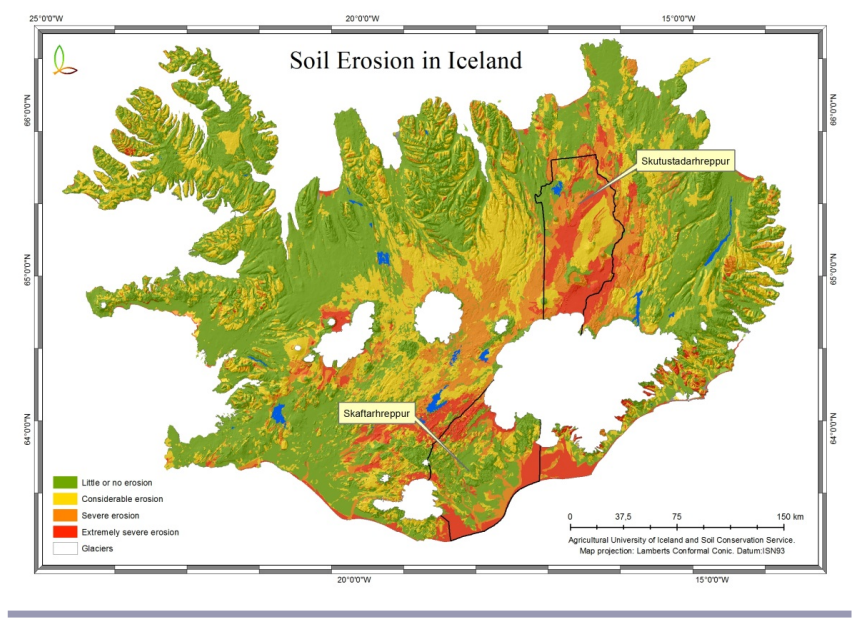

participatory approaches started as an experimental project in only one region but soon developed into a nationwide project, based on voluntary participation. In 2010, around 600 landowners participated in the project (Petursdottir 2011).

\section{Visiting and Interviewing Stakeholders}

Our case study was based on two qualitative surveys, where semistructured interviews were used to interview preselected stakeholders. The first survey (A) was conducted in June 2009, when 10 sheep farmers were visited and interviewed by a team of two experts, a national expert (Petursdottir) and a visiting European expert (Montanarella). The farmers were asked about their attitudes toward land use, soil conservation, restoration, and agri-environmental policies. The second survey (B) consisted of interviews conducted by the lead author with five agricultural or environmental officials on the same discussion topics as in the previous survey.

\section{(A) Sheep farmers}

The survey was conducted within two rural municipalities (Skaftarhreppur in the southeast and Skutustadahreppur in northeast Iceland) that have in common a strong reliance on sheep farming (Table 1) and tourism (Júlíusdóttir et al. 2009). Both municipalities lie within the volcanic belt of Iceland and have severely degraded ecosystems that are, in part, still under the threat of soil erosion (Fig. 1). Sheep farming is the main agricultural activity in both municipalities (Table 1), but tourism is also an important economic activity (Júlíusdóttir et al. 2009). The municipalities are located far from urban areas but both contain a small village that serves the surrounding countryside (Table 1). Vatnajokull national park stretches into 
Table 1. Background information for Skaftarhreppur and Skutustadahreppur

\begin{tabular}{|c|c|c|}
\hline & Skaftarhreppur & Skutustadahreppur \\
\hline \multicolumn{3}{|l|}{ Demographic (number) } \\
\hline Total population & 443 & 385 \\
\hline Villages/population & Kirkjubæjarklaustur/115 & Reykjahlíð/160 \\
\hline Total farmsteads & 34 & 26 \\
\hline BGL participants & 27 & 15 \\
\hline \multicolumn{3}{|l|}{ Livestock (total number) } \\
\hline Sheep & 20,574 & 4799 \\
\hline Cattle & 1824 & 392 \\
\hline Horses & 632 & 111 \\
\hline \multicolumn{3}{|l|}{ Geographic } \\
\hline Location & SE coast & NE inland \\
\hline Elevation (m.a.s.1.) & $<100-300$ & $350-450$ \\
\hline Mean annual temperature $\left({ }^{\circ} \mathrm{C}\right)$ & 4.5 & 1.4 \\
\hline Annual precipitation $(\mathrm{mm})$ & 1645 & 435 \\
\hline \multicolumn{3}{|l|}{ Area $\left(\mathrm{km}^{2}\right)$} \\
\hline Total size & 6946 & 6036 \\
\hline Size of lowland & 1411 & 931 \\
\hline Size of highland & 2761 & 3858 \\
\hline Restoration areas & 208 & 137 \\
\hline \multicolumn{3}{|l|}{ Vegetation condition $(\%)$} \\
\hline Vegetated lowland & 25 & 42 \\
\hline Poorly vegetated lowland & 49 & 32 \\
\hline Barren lowland & 26 & 25 \\
\hline Vegetated highland & 5 & 0 \\
\hline Poorly vegetated highland & 31 & 1 \\
\hline Barren highland & 64 & 98 \\
\hline Vegetated restoration areas & 6 & 20 \\
\hline Poorly vegetated restoration areas & 25 & 23 \\
\hline Barren restoration areas & 69 & 57 \\
\hline
\end{tabular}

both of the municipalities, and both of them contain also other types of protected areas. The presence of a hydropower plant within the Skutustadahreppur region provides inhabitants with access to more varied job opportunities than those available to the inhabitants of Skaftarhreppur. However, Skaftarhreppur is one of several rural areas in Iceland that have officially been defined as highly dependent upon sheep farming, and therefore, farmers in Skaftarhreppur benefit from somewhat higher subsidies than those in Skutustadahreppur (Júlíusdóttir et al. 2009).

The main criteria used for selecting the participants were: (1) farms with more than 200 adult sheep, (2) farmers participating in the FHL restoration program, and (3) dissimilar attitudes toward land use and restoration. Local SCSI district officers were asked to identify and contact several farmers who they believed would fulfill these preset criteria. All the farmers who were contacted agreed to participate. Ten farmsteads were visited, and the farmers interviewed informally. The participants' ages ranged from 40-65 years, and all had practiced sheep farming for 20 years or more. Eight of the participants had additional sources of income apart from that gained through farming, such as through tourism or paid employment outside the farm. The farmers were informed beforehand about the research background, and matters of research ethics, such as participants' anonymity, were clearly stated.

The interviews were based on several key questions related to land management, soil conservation, and restoration, but the interviewees could also discuss other issues. In cases where the interviewee did not speak English, the national expert translated the conversation. Most of the visits took 3-4 hours. They started at the interviewee's home but were followed up by fieldtrips to explore each farmstead's restoration areas. The interviews were not recorded, but the main discussions points were documented by the interviewers after each visit.

\section{(B) Agricultural and environmental officials}

Five officials were defined as key informants, all with considerable experience in working in the public sector and in direct involvement in management and policy settings for agri-environmental topics. The officials were contacted by email and asked to participate. They were also informed about the research background, and again, matters related to research ethics were clearly stated. All the contacted people agreed to 
Table 2. An overview of the participants' attitudes on land use/restoration, collaboration, and governance.

\begin{tabular}{|c|c|c|c|c|c|}
\hline & Profession & Location & Land use/restoration & Collaboration & Governance \\
\hline \multicolumn{6}{|c|}{ Farmers } \\
\hline 1 & Sheep farmer & Skaftarhreppur & 0 & 0 & $0 /-$ \\
\hline 2 & "، & “ 11 & ++ & + & $+/-$ \\
\hline 3 & “ & “ & ++ & ++ & 0 \\
\hline 4 & “ & “ & ++ & ++ & $+/-$ \\
\hline 5 & Sheep/Dairy farmer & “ & ++ & ++ & ++ \\
\hline 6 & “ & Skutustadahreppur & ++ & + & 0 \\
\hline 7 & Sheep farmer & " & ++ & + & + \\
\hline 8 & “ & “ & ++ & + & $+/-$ \\
\hline 9 & “ & “ & ++ & + & $+/-$ \\
\hline 10 & “ & “ & ++ & ++ & ++ \\
\hline \multicolumn{6}{|c|}{ Officials } \\
\hline 1 & Director & Reykjavik & ++ & ++ & $+/-$ \\
\hline 2 & Parliamentarian & “ & ++ & ++ & ++ \\
\hline 3 & Director & “ & ++ & ++ & $+/-$ \\
\hline 4 & Director & “ & ++ & ++ & $+/-$ \\
\hline 5 & Director & “ & ++ & + & $+/-$ \\
\hline
\end{tabular}

participate. They were interviewed during the period from October to December 2009. Each participant was visited at his/her office and interviewed for about 1.5 hours. The interviews were semistructured, i.e., the interviewer followed a list of open questions based on the preselected topics used in the previous survey. This list of questions was followed through in each interview, but the participants could also discuss other related issues.

All the interviews were taped, and in two cases, the interviewer added additional information from her field notes. Afterward, each interview was typed up and treated by a coding method (Taylor and Bogdan 1998). The average length of each completed interview was about 30 pages. Due to the small size of the Icelandic agri-environmental public sector and in order to protect interviewees' anonymity, officials were coded based on the sector in which they were employed and not based on their profession.

The results from both surveys were divided into three categories: (a) Land use/Restoration, (b) Collaboration, and (c) Governance. These three categories were used as the setup for a table where each participant's attitude was roughly ranked, based on his/her view in comparison with the other participants' views on the same category. The symbols "+", "-", and " 0 " were used to distinguish among their attitudes, where "." signified a negative view, "0" a neutral view, and "+" a positive view. Two symbols were used if the participant expressed a strong positive or strong negative view.

\section{RESULTS}

\section{Land use/Restoration}

The interviewed farmers usually agreed on the importance of soil conservation and restoration and claimed that rangeland management had improved during the last three decades (Table 2). They mentioned several reasons for this improvement, including improved technology for hay making leading to more quantity and quality of fodder for the sheep during the winter and in early spring, and less grazing pressure due to fewer sheep. They maintained that, due to improved information provided by the advisory services, farmers are now more aware than in the past about the degradation risk associated with following winter and early spring grazing, a customary practice until the 1970 s. They particularly noted that the restoration support system offered by the SCSI had increased awareness among farmers about how rangeland restoration and rangeland management could be improved.

The farmers mentioned several reasons why they practice restoration. Those most commonly acknowledged were rooted in moral values, such as respect and care for the land. They stated that it was their responsibility to "heal" degraded land for its own sake and improve its condition for future generations. The majority of the farmers were also restoring to improve rangeland condition or the land's esthetic values as a tourist attraction, but only a few of them mentioned economic reasons, such as improved productivity, as the main rationale for their restoration activities.

The officials also usually agreed with the importance of soil conservation and viewed sustainable land management and restoration as important factors in maintaining healthy ecosystems and in improving the condition of degraded ecosystems (Table 2). However, their view on restoration was based on different perspectives. Those working in the agricultural sector claimed that restoration activities should primarily be aimed at optimizing land use. As one of them said: “...in my mind, restoration is a certain activity made to 
trigger vegetation growth... to change the color of sparsely vegetated or barren land to a green one." In contrast, the interviewees working in the environmental sector mentioned the importance of restoring ecosystem services and improved biological diversity as the main reasons for restoration. One of them stated: “...very important factors are of course to protect/maintain what still exists and restore lost vegetation and degraded ecosystems." They also noted the national obligations to fulfill commitments related to international conventions, such as the Convention on Biological Diversity (CBD) and the United Nations Convention to Combat Desertification (UNCCD).

\section{Collaboration}

Restoration activities appeared to have a strong social value among the farmers we interviewed in Skaftarhreppur. Some of them were volunteers in restoration projects and covered a substantial part of the projects' direct costs themselves. Most of the farmers were also members of the local restoration NGO (Landgræðslufélag Skaftarhrepps). This NGO was founded in 1994 by local stakeholders with the aim of supporting restoration of degraded land within Skaftarhreppur and strengthening the inhabitants' awareness of and education on the issue. All the work conducted by the NGO is undertaken on a voluntary basis, but the SCSI provides chemical fertilizer and grass seed when needed.

In Skutustadahreppur, restoration activities appeared to have less social value. The farmers worked individually on restoration on their own farmland, generally in collaboration with the SCSI, but did not seem particularly motivated to participate in voluntary work outside the farm. The restoration activities in Skutustadahreppur appeared to be more directly related to the availability of direct incentives, such as external funding, compared with Skaftarhreppur, and even though there was one large joint restoration project ongoing in Skutustadahreppur, it was managed through an NGO (Húsgull) from an adjacent area, and the work within the project was mainly carried out by contractors.

All the participants interviewed considered restoration projects to some extent to have societal as well as ecological importance. They commonly felt that the design of restoration projects and the corresponding action plans should be based on collaboration between stakeholders and that the majority of the annual costs of ecological restoration projects should be funded by the government, irrespective of the ownership of the degraded land in question.

The participants favored the use of participatory approaches regarding restoration activities, seeing them as leading to more efficient outcomes than activities where decisions and related management are organized in a top-down manner by the authorities. As one of the agricultural officials phrased it: “... the fact that when people work together; it increases trust and it shares knowledge...." The officials especially mentioned "bottom-up" methods, including working with stakeholders on a local scale, as examples of successful collaboration between farmers and the related governance system.

\section{Governance}

Some of the farmers felt that they lacked a stronger connection to agri-environmental agencies. They felt that officials often lacked a deeper insight into sheep farming and should visit the countryside more often to build up and strengthen mutual trust between farmers and the relevant authorities.

The participants generally stated that there was a lack of comprehensive government policy regarding land use and management. The officials argued that such a policy should not be based on the vision of individual ministries but should instead be developed jointly by the concerned ministries using multidisciplinary approaches. The following statement by an environmental official reflected this view: “....as the Icelandic governance is designed, we have put emphasis on, in contrast to many other countries, to have small ministries and strong agencies and actually put it into the hands of these agencies to formulate their own policies and prioritize projects and as it is built, it has mostly been in their [the agencies] hands."

According to some of the officials, this situation has given the agencies freedom to shape their own policies. Consequently, it seems to have given them more autonomy to focus on specific single issues. These types of single policy targets have, over the years, become informally accepted by the national governments (although they were never legally valid), as part of governmental laws or legislations. This development seems to have caused friction between governmental agencies and obscured who is the leading authority within different political or scientific fields. As one of the environmental officials phrased it: "...well, I say that some of the agencies are far too small... and they are individually given projects that should be handled by only one agency...."

Many of the officials felt that the optimal solution would be for the government to set a broad overall policy framework, within which the governmental agencies have the freedom to shape their policies. They considered this an efficient way because the professional knowledge needed for policy making is located within the agencies, and they themselves are, therefore, best suited to identify how best to use their resources. However, officials were somewhat pessimistic and mentioned that perhaps the governments lacked the will to create such a comprehensive policy framework. One of the agricultural officials said that: "...humans never want to give up the power they had, you see, although it serves the public interests to do so ... I think it's as simple as that." In addition, an environmental official stated that there was strong opposition to such a move among many stakeholder groups: "...there are such strong forces that don't want a comprehensive overview." 
Some mentioned that parliamentarians might also lack the political strength needed to run such multidisciplinary actions. Local pressure from the electorate could also influence their decision making and possibly outweigh unpopular decisions. As one of the agricultural officials stated: "...if only it was, well just a strong political leadership here... we know always how the politicians are...."

The officials seemed to view the agricultural and the environmental sectors as distinct entities. They felt that the environmental and agricultural agencies and ministries often have a tendency to operate in a too institutionally "selfcentered" manner, not being receptive to cooperation or transparent discussions on joint topics. They stated that this could increase the risk of overlapping or duplication of work and most likely decrease the institutional efficiency in the agrienvironmental field. As one environmental official put it: “... we are a society with an enormous "silo-mentality" when it comes to institutions' structure....\#8221; another environmental official said: "...just to talk straight out... this system is obviously a system of "chiefs' monarchy"...."

There seemed to be an underlying tension between the environmental and agricultural sectors, and the transfer of the SCSI from the Ministry of Agriculture to the Ministry of Environment in 2008 may have increased this friction. The agricultural officials felt the transfer had already weakened the ties between these two sectors and could probably lead to even further policy fragmentation. Nevertheless, environmental officials embraced these governance changes and felt they would lead to even more ecologically sound approaches to restoration.

\section{DISCUSSION}

The social-ecological system of rangeland restoration and rangeland management in Iceland is driven by agrienvironmental policies, controlled by law, regulations, or other direct governmental decisions and supported and managed by related ministries and agencies. By interviewing selected sheep farmers and officials, we gathered information about their attitudes toward restoration and rangeland management and how they felt that agri-environmental policies, and the related SESs, were functioning.

For over a century, the importance of soil conservation and restoration has been emphasized in the political setting and scientific discussions in Iceland, and in recent decades, there has been increasing awareness among farmers of the need to adopt a solution-orientated approach to policy making (Barkarson and Johannesson 2009). In this research, sheep farmers showed, by and large, a positive attitude toward soil conservation and restoration, in line with results from other studies (Schmidt 2000; Berglund et al. 2013).

A national survey of soil erosion in Iceland completed in 1997 revealed severe soil erosion in $40 \%$ of the country (Arnalds et al. 2001). Current summer grazing on most of these highly eroded areas, especially in the highlands, is limiting the natural succession of degraded ecosystems (Magnusson and Svavarsdottir 2007). Despite this, the majority of sheep farmers still apply traditional methods and practices of land use (Arnalds and Barkarson 2003). Aside from shortening the grazing period over the past 50 years, from year-round to about 6 months with still shorter periods (2-3 months) in the highland commons, most of the farmers we interviewed continue to practice rangeland management in the traditional way of free-range grazing on commons. Only one of the interviewed farmers had entirely changed his grazing management, grazing only on fenced-off, private land instead of on the commons.

Even though sheep farming is highly subsidized by government, the annual income of a sheep farm is relatively low and, in many cases, not sufficient to make a living (Júlíusdóttir et al. 2009). The majority of the farmers we interviewed had to generate additional income outside their farm. Nevertheless, they seemed to have a strong cultural disposition toward protecting their land. The farmers emphasized moral values, such as respect and care for the land, as reasons for restoration and the duty "to pay the debt to the land" seemed to be deeply rooted in their mindset. Severe problems with drifting sand in the first half of the 20th century are still relatively close in time, and stories from that period continue to shape and influence the values that are held by current farmers (Crofts 2011). For several decades, the slogan "to pay the debt to the land" was used to raise awareness about soil conservation and land restoration (Aradóttir et al. 2013), which may also have influenced farmers' attitudes toward land restoration (Arnalds 2005).

Governments have a critical role in natural resource management. A well-structured governance system that brings well-designed regulations, policies, and incentives is essential to understanding and maintaining the sustainability of an SES (Liu et al. 2007). According to Basurto and Coleman (2010), strong institutions at higher levels can maintain trust and stability while also facilitating adaption to ecological conditions and social concerns at finer scales. Our results indicate that the SESs of rangeland restoration might be lacking such institutional strength. They point to key weaknesses, such as the lack of transparency within the governance system and the perceived lack of institutional cooperation and collaboration at higher levels. These problems have the potential to reduce the coherence of political decisions on rangeland restoration and sustainable land management.

The interviews with the farmers demonstrated noticeable differences in the farmers' willingness to cooperate in communal restoration activities between the two communities. The farmers living in Skaftarhreppur seemed to be collaborating more actively and taking more part in 
voluntary work, compared with the farmers in Skutustadahreppur. Before 1990, the SCSI commonly used top-down approaches to carry out soil conservation and restoration, mostly without any direct local cooperation and involvement (Arnalds 2005). This often led to tensions and disagreements between the agency and the farmers (Barkarson and Johannesson 2009). This was the case in Skutustadahreppur, where strong resistance to the SCSI eventually led to the establishment of the FHL project in 1990 (Arnalds 2005).

Using participatory approaches requires understanding of how participation can impact on project implementation, because the outcomes of participatory projects depend mostly on how process factors, such as project aims, power division, and interactions between participants, are attended to in the implementation process (Berglund et al. 2013). That the FHL project started in Skutustadahreppur, when participatory approaches were poorly developed, possibly led to fewer participatory practices between farmers and SCSI in that area. This factor and the previously mentioned resistance to the SCSI may help explain why the farmers in Skutustadahreppur seem to perceive the incentives provided by the SCSI as a direct subsidy, as opposed to the farmers in Skaftarhreppur, who may well see the incentives more as a stimulus for restoration and cooperation. The lower social importance of restoration activities in Skutustadahreppur than in Skaftarhreppur may, however, also be related to other issues, such as more employment opportunities in Skutustadahreppur or differences in the local advisory service.

Our results indicate high awareness among the farmers of the importance of restoration. Furthermore, bottom-up approaches seem to have successfully motivated all the farmers we interviewed to practice restoration. However, they have apparently not managed to trigger any general shifts toward improved rangeland management, even though that was the underlying policy target. The lack of change in behavior can possibly be ascribed to the traditions of land use, as cultural inertia can make it difficult to make necessary changes (cf. Liu et al. 2007). But it could also be related to the lack of strong institutional structure and strong regulations and/or to underlying institutional sluggishness and resistance to change (Barkarson and Johannsson 2009).

Management systems should be dynamic, but too often the internal inertia between and within institutions tends to dominate many aspects of natural resource management (e.g., Liu et al. 2007). The agencies involved may lack the administrative capacity to take a systematic approach to the design of restoration or land management programs and may fail to use policy instruments that are consistent with economic conditions, landholders' needs, and attitudes toward land management (Tarlock 1993). In our case, the current institutional structure splits the agri-environmental subjects into small administrative units managed by separate agencies, resulting in fragmentation and maintenance of the perceived institutional "silo mentality." These results agree with the findings of Niedziałkowski et al. (2012), who found that power relationships and vested interests can become the main drivers of a governance system without bringing gains in legitimacy or new policy options.

It can be complicated to reach a desired ecological outcome from restoration activities, especially in larger areas where inhabitants base their livelihood on using the degraded systems in question. The progress of a large-scale restoration, therefore, relies not only on ecological and environmental factors but also on the sustainability of the related SESs (Berkes and Folke 2000). These complications are clearly demonstrated by the outcome of the interviews in this research, e.g., how the farmers' positive attitudes toward restoration apparently fail to influence their rangeland management practices, or the perceived lack of cooperation between the agricultural and environmental sectors that may be preventing desired policy effectiveness.

Impacts of natural resource management projects are mainly evaluated by focusing on the attitude and behavior of those who are using the resources, but less emphasis is placed on analyzing the attitudes of other related stakeholder groups and relevant governmental and nongovernmental officials (Tuvendal and Elmqvist 2011). Our results strongly indicate that lack of effectiveness in the governance of the SESs can hamper the desired progress of policies related to large-scale natural resource management projects such as rangeland restoration. It can also block the necessary paradigm shift among stakeholders regarding rangeland management. We conclude that the sustainability of the SESs can be improved by the establishment of more comprehensive agrienvironmental policies and by strengthening the interconnections between the different institutional agents and actors involved in the governance of this policy arena. But, as this study is based on results collected from a small sample, it only gives certain indications as to the existence of gaps and disconnectivities within the SESs.

We find an SES analysis useful for exploring the impact of restoration programs. But to achieve more robust results, we suggest a further development of the method to use on a larger scale, preferably a national one. Such analysis would be highly valuable for the development of stronger agri-environmental policies and for enhancing the sustainability of rangeland restoration and rangeland management within the SESs.

Responses to this article can be read online at: http://www.ecologyandsociety.org/issues/responses. $\mathrm{php} / 5399$ 


\section{Acknowledgments:}

The Energy Research Fund of Landsvirkjun and the Agricultural Productivity Fund in Iceland provided funds for the study. We thank the Soil Conservation Service of Iceland for funding the field trips to Skaftarhreppur and Skutustadahreppur and the farmers and the officials who participated in the study.

\section{LITERATURE CITED}

Alpingi [the National Assembly]. 1996. Parliamentary document 1108-389 case. [online] URL: http://www.althingi. is/altext/stit/1996.073.html

Anderies, J. M., M. A. Janssen, and E. Ostrom. 2004. A framework to analyze the robustness of social-ecological systems from an institutional perspective. Ecology and Society 9: 18. [online] URL: http://www.ecologyandsociety.org/vol9/ iss1/art18/

Aradóttir, Á. L., and p. Pétursdóttir. 2011. Opinber stefnumótun og stjórnsýsluhvatar er varða vistheimt á Íslandi [Policies and incentives for ecological restoration in Iceland]. Pages 24-30 in Á. L. Aradóttir and G. Halldórsson, editors. Vistheimt á Íslandi [Ecological restoration in Iceland]. The Agricultural University of Iceland and the Soil Conservation Service, Reykjavik, Iceland.

Aradóttir, Á. L., p. Pétursdóttir, G. Halldorsson, K. Svavarsdottir, and O. Arnalds. 2013. Drivers of ecological restoration - lessons from a century of restoration in Iceland. Ecology and Society 18 in press.

Arnalds, A. 2005. Approaches to landcare-a century of soil conservation in Iceland. Land Degradation and Development 16:1-13. http://dx.doi.org/10.1002/ldr.665

Arnalds, O. 2008. Soils of Iceland. Jökull 58:409-421.

Arnalds, O., and B. H. Barkarson. 2003. Soil erosion and land use policy in Iceland in relation to sheep grazing and government subsidies. Environmental Science and Policy 6:105-113. http://dx.doi.org/10.1016/S1462-9011(02)00115-6

Arnalds, O., E. F. Thorarinsdottir, S. Metusalemsson, A. Jonsson, E. Gretarsson, and A. Arnason. 2001. Soil erosion in Iceland. Soil Conservation Service and the Agricultural Research Institute, Reykjavik Iceland. (Translated from Icelandic Version.)

Aronson, J., J. N. Blignaut, S. J. Milton, D. Le Maitre, K. J. Esler, A. Limouzin, C. Fontaine, M. P. de Wit, W. Mugido, P. Prinsloo, L. van der Elst, and N. Lederer. 2010. Are socioeconomic benefits of restoration adequately quantified? A meta-analysis of recent papers (2000-2008) in Restoration
Ecology and 12 other scientific journals. Restoration Ecology 18:143-154. http://dx.doi.org/10.1111/j.1526-100X.2009.00638. $\underline{\mathrm{X}}$

Barkarson, B. H., and M. H. Johannsson. 2009. Arctic landcare. Pages 55-63 in D. Catacutan, C. Neely, M. Johnson, H. Poussard, and R. Youl, editors. Landcare: Local actionglobal progress. World Agroforestry Centre, Nairobi, Kenya.

Basurto, X., and E. Coleman. 2010. Institutional and ecological interplay for successful self-governance of community-based fisheries. Ecological Economics 69:10941103. http://dx.doi.org/10.1016/j.ecolecon.2009.12.001

Berglund, B., L. Hallgren, and Á. L. Aradóttir. 2013. Cultivating communication: participatory approaches in land restoration in Iceland. Ecology and Society 18 in press.

Berkes, F., and C. Folke. 2000. Linking social and ecological systems for resilience and sustainability. Pages 1-25 in F. Berkes and C. Folke editors. Linking social and ecological systems, management practices and social mechanisms for building resilience. Cambridge University Press, Cambridge, UK.

Bjarnason, E. 1992. Leiðbeiningapjónusta í landbúnaði [Advisory service in agriculture]. In Ráðunautafundur. BÍ, RALA: 211-222.

Bradshaw, G. A., and M. Bekoff. 2001. Ecology and social responsibility: the re-embodiment of science. Trends in Ecology and Evolution 16:460-465. http://dx.doi.org/10.1016/ $\underline{\text { S0169-5347(01)02204-2 }}$

Clewell, A. F., and J. Aronson. 2006. Motivations for the restoration of ecosystems. Conservation Biology 20:420-428. http://dx.doi.org/10.1111/j.1523-1739.2006.00340.x

Crofts, R. 2011. Healing the land, the story ofland reclamation and soil conservation in Iceland. Soil Conservation Service, Reykjavik, Iceland.

Daly, H. E., and J. Farley. 2004. Ecological economics, principles and applications. Island Press, Washington, D.C., USA.

Herling, M. C., C. F. Cupido, P. J. O'Farrell and L. Du Plessis. 2008. The financial costs of ecologically nonsustainable farming practices in a semiarid system. Restoration Ecology 17:827-836. http://dx.doi.org/10.1111/j.1526-100X.2008.00419. $\underline{x}$

Hobbs, R. J. 2007. Setting effective and realistic restoration goals: key directions for research. Restoration Ecology 15:354-357. http://dx.doi.org/10.1111/j.1526-100X.2007.00225. $\underline{x}$ 
Hobbs, R. J., L. M. Hallett, P. R. Ehrlich, and H. A. Mooney. 2011. Intervention ecology: applying ecological science in the twenty-first century. Bioscience 61:442-450. http://dx.doi. org/10.1525/bio.2011.61.6.6

Holling, C.S. 2001. Understanding the complexity of economic, ecological and social systems. Ecosystems 4:390405. http://dx.doi.org/10.1007/s10021-001-0101-5

Icelandic Agricultural Statistic. 2010. The Farmers Association of Iceland.

Ingimundarson, J. H. 2010. Comparative-historical analysis of farming systems and agricultural intensification in medieval and early modern Iceland. Pages 319-337 in G. Winther and R. D. Rasmussen, editors. Political economy of northern regional development. Nordic Council of Ministries Publication, Copenhagen, Denmark.

Jóhannesson, T. 2010. Agriculture in Iceland: condition and characteristics. The Agricultural University of Iceland, Reykjavik, Iceland. [online] URL: http://www.lbhi.is/lisalib/ getfile.aspx?itemid $=4090$

Jónsson, J. 1985. Staða og framtíðarhorfur í leiðbeiningapjónustu [Current situation and future prospects of of advisory services]. In Ráðunautafundur. BÍ, RALA:8-19.

Júlíusdóttir, M., A. Karlsdóttir, K. Benediktsson, I. E. Vésteinsdóttir, and S. Steingrímsson. 2009: Litróf búskapar og byggða: Fjölpaettur landbúnaður á Íslandi [The spectrum of farming and settlement: multifunctional agriculture in Iceland]. Háskóli Íslands, Reykjavik, Iceland.

Liu, J., T. Dietz, S. R. Carpenter, M. Alberti, C. Folke, E. Moran, A. N. Pell, P. Deadman, T. Kratz, J. Lubchenco, E. Ostrom, Z. Ouyang, W. Provencher, C. L. Redman, S. H. Schneider, and W. W. Taylor. 2007. Complexity of coupled human and natural systems. Science 317:1513-1516. http:// dx.doi.org/10.1126/science.1144004

Magnússon, S. H., and K. Svavarsdóttir. 2007. Áhrif beitarfriðunar á framvindu gróðurs og jarðvegs á lítt grónu landi [Effects of sheep grazing protection on succession in sparsely vegetated areas in Iceland]. Fjölrit Náttúrufræðistofnunar No. 49.

McGovern, T. H., O. Vesteinsson, A. Fridriksson, M. Church, I. Lawson, I. A. Simpson, A. Einarsson, A. Dugmore, G. Cook, S. Perdikaris, K. J. Edwards, A. M. Thomson, W. P. Adderley, A. Newton, G. Lucas, R. Edvardsson, O. Aldred, and E. Dunbar. 2008. Landscapes of settlement in northern Iceland: historical ecology of human impact and climate fluctuation on the millennial scale. American Anthropologist 109:27-51. http://dx.doi.org/10.1525/aa.2007.109.1.27

Meadows, D. H. 2008. Thinking in systems: a primer. Chelsea Green. White River Junction, Vermont, USA.
Niedziałkowski, K., J. Paavola, and B. Jędrzejewska. 2012. Participation and protected areas governance: the impact of changing influence of local authorities on the conservation of the Białowieża Primeval forest, Poland. Ecology and Society 17(1): 2. http://dx.doi.org/10.5751/ES-04461-170102

O'Farrell, P. J., W. J. De Lange, D. C. Le Maitre, B. Reyers, J. N. Blignaut, S. J. Milton, D. Atkinson, B. Egoh, A. Maherry, C. Colvin, and R. M. Cowling. 2011. The possibilities and pitfalls presented by a pragmatic approach to ecosystem service valuation in an arid biodiversity hotspot. Journal of Arid Environments 75:612-623. http://dx.doi.org/10.1016/j. jaridenv.2011.01.005

Ostrom, E. 2009. A general framework for analyzing sustainability of social-ecological systems. Science 325:419422. http://dx.doi.org/10.1126/science.1172133

Pétursdóttir, p. 2011. Bændur græða landið - samstarf um uppgræðslu og endurheimt vistkerfa [Farmers heal the land - a cost share program on revegetation and ecological restoration of ecosystems]. Pages 84-85 in Á. L. Aradóttir and G. Halldórsson, editors. Vistheimt á Íslandi [Ecological restoration in Iceland]. The Agricultural University of Iceland and the Soil Conservation Service, Reykjavik, Iceland.

Runólfsson, S., and A. M. Ágústsdóttir. 2011. Restoration of degraded and desertified lands: experience from Iceland. Pages 153-161 in R. Lal, M. V. K. Shivakumar, S. M. A. Faiz, A. H. M. M. Rahman, and K. R. Islam, editors. Climate change and food security in South Asia. Springer, Dordrect, The Netherlands. http://dx.doi.org/10.1007/978-90-481-9516-9 11

Schmidt, G. 2000. Bændur græða landið - viðhorf bænda [Farmers reclamation project - the farmers' attitude]. In Rádunautafundur. BÍ, LBH, RALA: 93-9.

Society for Ecological Restoration Science and Policy Working Group (SER). 2004. The SER international primer on ecological restoration. Society for Ecological Restoration International, Tucson, Arizona, USA. [online] http://www.ser. org/pdf/primer3.pdf

Society for Ecological Restoration International and IUCN Commission on Ecosystem Management. 2004. Ecological restoration, a means of conserving biodiversity and sustaining livelyhood. Society of Ecological Restoration International, Tucson, Arizona, USA and IUCN, Gland, Swizerland. [online] URL: https://www.ser.org/pdf/Global_Rationale.pdf

Stefánsson, G. 1998. Landbúnaðarstefnan og búvörusamningar [The agricultural policy and agricultural agreements]. In Rádunautafundur. BÍ, LBH, RALA: 3-12.

Tarlock, A. D. 1993. Local government protection of biological diversity: what is its niche? The University of Chicago Law Review 60:555-613. http://dx.doi.org/10.2307/1600079 
Taylor, S. J., and R. Bogdan. 1998. Introduction to qualitative research methods. Third edition. Wiley, New York, New York, USA.

Tuvendal, M., and T. Elmqvist. 2011. Ecosystem services linking social and ecological systems: river brownification and the response of downstream stakeholders. Ecology and Society 16(4): 21. http://dx.doi.org/10.5751/ES-04456-160421

Weber, M. A., and S. Stewart. 2008. Public values for river restoration options on the middle Rio Grande. Restoration Ecology 17:762-771. http://dx.doi.org/10.1111/ j.1526-100X.2008.00407.x 